University of Montana

ScholarWorks at University of Montana

10-2004

\title{
Novel Weapons: Invasive Success and the Evolution of Increased Competitive Ability
}

\author{
Ragan M. Callaway \\ University of Montana - Missoula, Ray.Callaway@mso.umt.edu \\ Wendy M. Ridenour
}

Follow this and additional works at: https://scholarworks.umt.edu/biosci_pubs

Part of the Biology Commons

Let us know how access to this document benefits you.

\section{Recommended Citation}

Callaway, Ragan M. and Ridenour, Wendy M., "Novel Weapons: Invasive Success and the Evolution of Increased Competitive Ability" (2004). Biological Sciences Faculty Publications. 223.

https://scholarworks.umt.edu/biosci_pubs/223

This Article is brought to you for free and open access by the Biological Sciences at ScholarWorks at University of Montana. It has been accepted for inclusion in Biological Sciences Faculty Publications by an authorized administrator of ScholarWorks at University of Montana. For more information, please contact

scholarworks@mso.umt.edu. 


\title{
Novel weapons: invasive success and the evolution of increased competitive ability
}

\author{
Ragan M Callaway and Wendy M Ridenour
}

When introduced to new habitats by humans, some plant species become much more dominant. This is primarily attributed to escape from specialist consumers. Release from these specialist enemies is also thought by some to lead to the evolution of increased competitive ability, driven by a decrease in the plant's resource allocation to consumer defense and an increase in allocation to size or fecundity. Here, we discuss a new theory for invasive success - the "novel weapons hypothesis". We propose that some invaders transform because they possess novel biochemical weapons that function as unusually powerful allelopathic agents, or as mediators of new plant-soil microbial interactions. Root exudates that are relatively ineffective against their natural neighbors because of adaptation, may be highly inhibitory to newly encountered plants in invaded communities. In other words, the novel weapons of some plant invaders provide them with an advantage that may arise from differences in the regional coevolutionary trajectories of plant communities. Furthermore, the selective advantage of possessing a novel weapon may result in rapid evolution of that weapon - for example, the production of greater quantities of allelopathic or antimicrobial root exudates. Direct selection of competitive traits provides an alternative to the "grow versus defend" trade-offs that underpin the theory of the evolution of increased competitive ability.

Front Ecol Environ 2004; 2(8): 436-443

$I^{n}$ the 13 th century, eastern and central Europe experienced one of the most surprising invasions in human history. The Mongols, once restricted to a small portion of central Asia, swept into Russia, Hungary, Poland, and Germany and consistently defeated much larger European armies. It was only the death of the Mongol leader, Ogedai Khan, in 1242, and the ensuing internal politics, that prevented Europe from becoming a collection of vassal states. The reasons for the success of the Mongol invasion were complex. Although it was in large part due to brilliant strategy and discipline, these strengths were derived from the possession of a novel weapon, the recurve bow carried by most Mongolian soldiers (Figure 1). The recurve bow

\section{In a nutshell:}

- The success of some exotic invasive plant species may be due to the possession of "novel weapons", biochemicals that native species have never encountered

- The novel weapons hypothesis raises the possibility of coevolution among plants in different regions of the Earth, and that mixing species from different regions increases the chances of disrupting the ecological processes that lead to species coexistence and greater community diversity

- Novel weapons suggest an alternative mechanism for the evolution of increased competitive ability in invasive plants. If invaders possess allelochemical weapons that provide greater competitive advantages in their new habitats than in their original ranges, then selection may act directly on those traits. We call this the "allelopathic advantage against resident species" hypothesis or "AARS"

Division of Biological Sciences, The University of Montana, Missoula, MT 59812 (ray.callaway@mso.umt.edu) fired arrows faster, farther, and with greater force than anything the Europeans had ever experienced. Such novel weapons have played a role in many human invasions, but novel biological weapons have only recently been considered as possible drivers of invasions by non-human exotic species. Here, we explore the possibility that novel weapons, biochemical in nature, play a part in the exotic plant invasions that are currently sweeping the world.

One of the mysteries in ecology is how exotic plants occurring at low densities in their native ranges attain extremely high densities in their introduced ranges (Figure 2). Although only a small fraction of introduced species have enjoyed such dramatic changes in fortune, these have had extensive economic impacts and suggest the existence of very powerful, yet poorly understood, ecological processes. A number of explanations for this invasion success have been proposed (Mack et al. 2000), but consumer-based hypotheses predominate - the "natural enemies hypothesis" (Williams 1954; Elton 1958; Crawley 1987, 1997; Mack et al. 2000; Maron and Vilà 2001; Levine et al. 2002) and a recent expansion of the natural enemies hypothesis, "the evolution of increased competitive ability" (EICA; Blossey and Nötzold 1995; Müller-Schärer et al. 2004).

The natural enemies hypothesis attributes exotic plant success to the fact that upon introduction many exotics are liberated from their specialist herbivores and pathogens. Exotics are thought to gain a substantial advantage because their populations are no longer directly suppressed by specialist consumers and pathogens, and because they obtain a competitive advan- 
tage over natives that may suffer disproportionately from attacks by these native enemies.

The EICA hypothesis argues that exotics long liberated from their native specialist enemies should lose costly traits that helped them resist those enemies. By evolving to allocate less resources to traits that conferred resistance to their specialist enemies, which are absent in the introduced range, exotics can use more resources for traits that provide greater competitive advantage, such as size or fecundity. Although the EICA hypothesis refers only to competitive ability, it was explicitly developed in the context of the "grow or defend" paradigm of allocation trade-offs (Herms and Matson 1992) and therefore reference to EICA implicitly attributes increased competitive ability to such trade-offs. The novel weapons hypothesis, described in detail below, addresses both invasive success and the evolution of increased competitive ability.

Convincing evidence exists for the natural enemies hypothesis as an explanation of some successful exotic invasions (Wolfe 2002; Mitchell and Power 2003; Reinhart et al. 2003; Siemann and Rogers 2003; Callaway et al. 2004; DeWalt et al. 2004; Jakobs et al. 2004), but there are reasons to be hesitant about accepting enemy release as the only reason for invasive success. First, there is evidence that the effects of natural enemies are weak on some invaders (Callaway et al. 1999; Ridenour and Callaway 2003; Lesica and Hanna 2004; Maron and Vilá 2001). Also, consumer effects can be similar in native and introduced ranges, (Beckstead and Parker 2003; Maron and Vilá 2001; Reinhart and Callaway in press), and in some habitats natives and exotics appear to receive similar amounts of damage (Agrawal and Kotanen 2003). Second, the literature on consumer-plant interactions in natural systems suggests that the relative impact of consumers is often minimal (Crawley 1989). Finally, little is known about the comparative effects of herbivores or pathogens on invasive plants in their native ranges versus their invaded ranges (see DeWalt et al. 2004 for an exception), and virtually nothing is known about the relative effects of consumers on the population ecology of invaders in native versus invaded ranges.

There is evidence for EICA (Daehler and Strong 1997; Willis and Blossey 1999; Siemann and Rogers 2001; 2003a,b; Leger and Rice 2003) and against it (Willis et al. 2000; Vilá et al. 2003; van Kleunen and Schmid 2003; Bossdorf et al. 2004; Maron et al. 2004). Although some invaders have been shown to be either larger or more fecund than similar species back in their native ranges, these studies have not shown that size confers greater competitive ability. Furthermore, no studies have explicitly linked greater size to the reallo- cation of resources or energy from defense against specialist herbivores to competitive ability.

\section{Biochemical novel weapons}

The role of consumer interactions in plant invasions must be crucial, but interactions between plants as determinants of invasive success have been overlooked. The novel weapons hypothesis that we propose holds that some exotics transform from native weaklings to invasive bullies by exuding biochemicals that are highly inhibitory (allelopathic) to plants or soil microbes in invaded communities, but relatively ineffective against natural neighbors that had adapted over time (Rabotnov 1982; Mallik and Pellisier 2000). Like the "guns, germs, and steel" used by human European invaders against indigenous peoples (Diamond 1997), the possession of novel weapons by some plant invaders provides them with an advantage that arises from regional differences in coevolutionary trajectories (Thompson 1999). To be precise, the definition of novel weapons here is limited to biochemicals released from invasive plants that affect native plants or the native soil biota, and with which native plants interact. For example, invasive plants may release biochemicals that alter the soil biota in ways that disadvantage native plants.

One manifestation of different regional evolutionary trajectories may be the huge number of different biochemicals produced by plants. So far, a compositionally diverse array of over 100000 different low-molecularmass natural products has been identified, many of which appear to be species-specific (Bais et al. 2002, 2003; Flores 1999). Far more are likely to be discovered. This rich diversity is probably due to selection pressures for many 


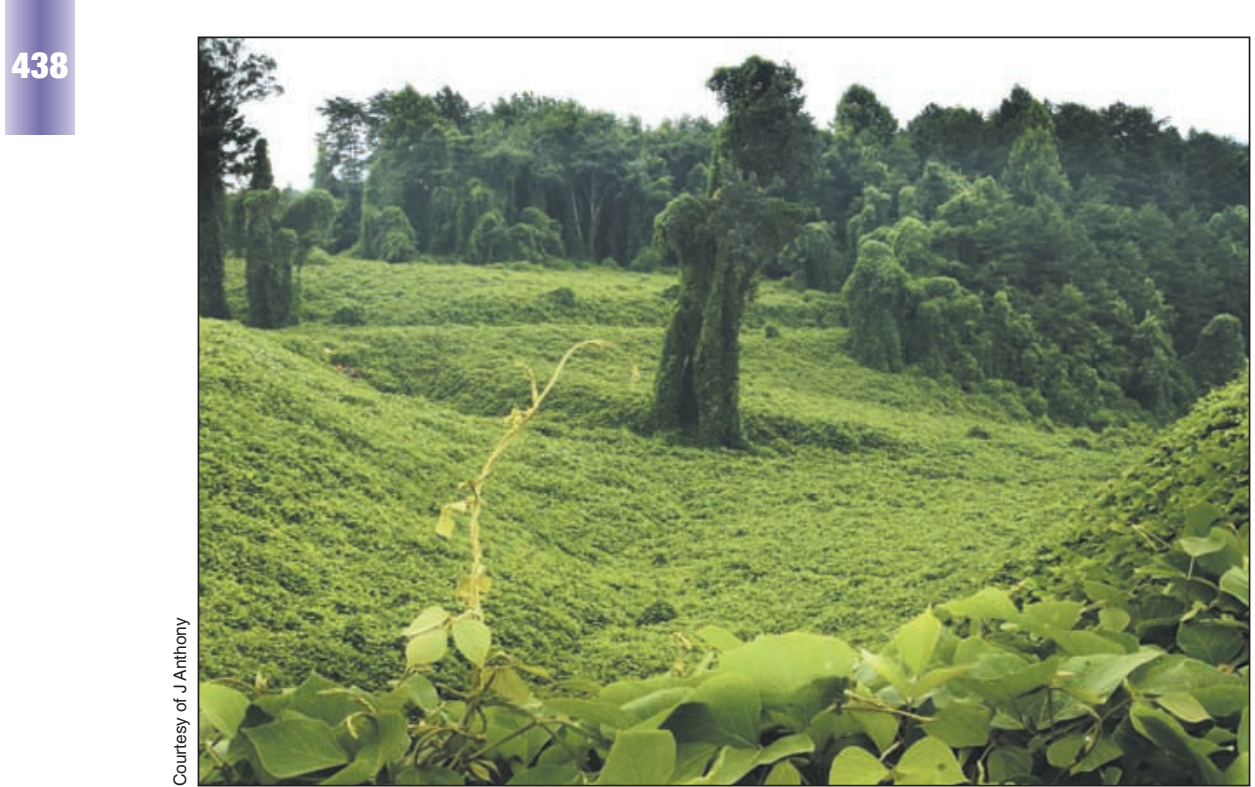

Figure 2. An invasive monoculture of kudzu (Pueraria montana) in the southeastern US. As with many exotic invasive plants, kudzu causes much more damage in its invasive range than in its native range.

different jobs, including soil nutrient acquisition, defense against herbivory, root communication, and antimicrobial protection. Alternatively, many biochemicals may be metabolic byproducts without particular functions. As described below for the examples of Centaurea maculosa, Centaurea diffusa, and Picea-Vaccinum communities, there is no reason to think that novel weapons must have originally evolved for the purpose of poisoning other plants. There may be good reason, however, to think that biochemicals, once evolved, can affect other plants, that other plants or microbes may evolve to tolerate the chemicals exuded by their neighbors, and that possession of novel weapons may lead to their proliferation.

The novel weapons hypothesis does have some strikes against it. First, little unambiguous evidence for it exists what is known is presented below. Second, the allelopathic mechanisms on which the hypothesis partially rests have a murky history (Callaway 2002), and allelopathy has been dismissed, perhaps unfairly, by many in plant community theory in favor of resource-driven interactions. On the other hand, biogeographic studies of allelopathic effects of invasive plants in natural and invaded communities may provide a new line of evidence for the role of allelopathy in community theory (Baldwin 2003; Fitter 2003). Finally, the notion that plant communities consist, even to a small extent, of species adapted to each other's rhizosphere biochemistry is unsettling to people raised on Whittaker's (1951) ideas about individualistic plant communities. Nevertheless, recent evidence suggests that geographic coevolutionary trajectories (Thompson 1999) based on unique biochemistry may affect plant coexistence and the development of communities; disruption of these trajectories by invaders may therefore have profound consequences (see also Callaway and Hierro in press; Callaway et al. in press).
Diffuse knapweed (Centaurea diffusa), a relatively minor member of a diverse genus, occurs naturally across Europe and Asia. Although capable of high densities immediately after agricultural disturbance in native systems, it is rarely as abundant, widespread, and dominant in its natural geographic range as it is in the western North American communities it has invaded (RM Callaway pers obs). While working in the foothills of the Caucasus Mountains, Callaway and Aschehoug (2000) observed that many of the genera outcompeted by $\mathrm{C}$ diffusa in North America appeared to coexist in relative peace with $\mathrm{C}$ diffusa in their native range (Figure 3 ). It did not seem likely that $\mathrm{C}$ diffusa would possess some profound competitive advantage for resources over North American species, yet not have similar advantages over species that were similar in size and phylogeny in the Caucasus. To test this, Callaway and Aschehoug collected seeds of $\mathrm{C}$ diffusa and several coexisting grass species in the Caucasus. They then grew the Caucasian species and related North American species in competition with the Caucasian C diffusa. Most importantly, they included treatments in which these competing species were grown in sand mixed with a small amount of activated carbon, a compound that absorbs organic molecules and has been used in previous experiments to ameliorate the allelopathic effects of root exudates of Centaurea maculosa and other species (Mahall and Callaway 1992; Ridenour and Callaway 2001).

They found that $\mathrm{C}$ diffusa suppressed the growth of North American species by about $70 \%$ more than it suppressed the growth of Caucasian species. Furthermore, activated carbon sharply reduced the inhibitory effect of C diffusa on the North American plants, but not its effect on the Caucasian plants. The story is more complicated, however, as $\mathrm{C}$ diffusa strongly suppressed the ability of North American species to acquire phosphorus-32 $\left({ }^{32} \mathrm{P}\right.$; a radioactive isotope of phosphorus), but had no influence on the Caucasian species in this regard. The effect on the North American plants was not altered by the presence of activated carbon. The reason for this difference is not known; it is possible, however, that activated carbon interfered with the phosphorus-chelating properties of $\mathrm{C}$ diffusa's root exudates (see below) as well as their toxic properties, and allelo-tolerant Eurasian grasses suffered from the adsorption of their neighbor's P-chelating root exudates.

Providing more mechanistic detail, Vivanco et al. (2004) identified a chemical in the root exudates of C diffusa, 8-hydroxyquinoline, which had not previously been reported as a natural product and which has strong metalchelating properties. Although they have similar effects, 8 -hydroxyquinoline is not related to $( \pm)$-catechin. They 
also found that experimental communities built from North American grass species were far more susceptible to invasion by $\mathrm{C}$ diffusa than communities built from Eurasian species, regardless of the biogeographical origin of the soil biota. These results correspond well with those of Callaway and Aschehoug (2000). In addition, 8-hydroxyquinoline applied to plants growing in field soils in pots suppressed the growth of North American species about 30\% more than it did the growth of Caucasian species. Considered as a package, the results of Callaway and Aschehoug (2000) and Vivanco et al. (2004) raise the possibility that Eurasian plants have evolved tolerance to the root exudates of $\mathrm{C}$ diffusa and a particular chemical constituent of $\mathrm{C}$ diffusa's root exudates, while North American plants have not. This suggests the possibility of evolved compatibility among plants within natural communities, and that the disruption of this compatibility can destroy these communities.

Mallik and Pellissier (2000) conducted experiments comparing the effects of leaves, leaf extracts, and humus from Vaccinium myrtillis, a widespread understory shrub in coniferous forests of Eurasia that has strong allelopathic effects, on an exotic North American neighbor, Picea mariana, and on a long-term native neighbor, Picea abies. They found that $V$ myrtillus generally had stronger biochemical effects on the exotic plant than on the native one. Their results also support the idea of a coevolutionary aspect to allelopathy (Rabotnov 1982).

Similar evidence exists for a plant in the same genus as $\mathrm{C}$ diffusa, the even nastier invader $\mathrm{C}$ maculosa. Probably introduced with alfalfa seed from Europe, it now occupies over 7 million acres of the US (http://www.fs.fed.us/data base/feis/plants/forb/cenmac/all.html; Figure 4). Like C diffusa, C maculosa is not a dominant, or even common, species in Europe. In the US, C maculosa has been the target of an aggressive biological control effort, with 13 species of insects introduced to control the weed. So far, biocontrol has not been successful (Müller-Schärer and Schroeder 1993; Pearson and Callaway 2003), suggesting that the lack of specialist insect herbivores is a minor component of its invasive success. In fact, specialist biocontrol root herbivory may stimulate the growth and competitive ability of C maculosa (Callaway et al. 1999;
Ridenour and Callaway 2003), an odd phenomenon that may be due to the effects of herbivory on the exudation of allelochemicals into the rhizosphere (GC Thelen and RM Callaway unpublished).

By integrating ecological, physiological, biochemical signal transduction, and genomic approaches to the root exudates of C maculosa, Bais et al. (2003) were able to isolate (-)-catechin, a chemical that has phytotoxic properties and is produced by $\mathrm{C}$ maculosa roots. Although unrelated chemically to 8-hydroxyquinoline, and not as rare in natural systems, (-)-catechin has been found in only a few plant species. Further supporting the novel weapons hypothesis, the germination and growth of European grasses were more resistant to $(-)$-catechin than were the germination and growth of naïve North American plants of the same genus.

Using a biogeographic approach similar to that of 


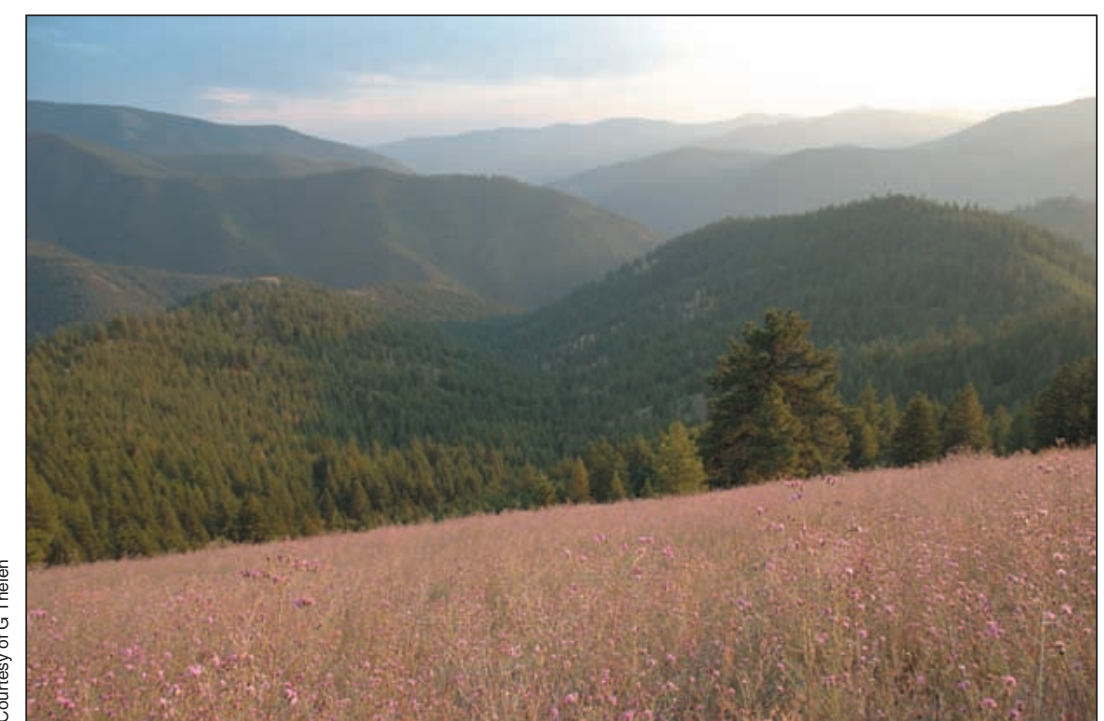

Figure 4. Centaurea maculosa, an invader of many communities in North America. The roots of this species exude large amounts of $( \pm)$-catechin, an isomer with chelating, phytotoxic, and antimicrobial properties.

Callaway and Aschehoug (2000), Prati and Bossdorf (2004) compared the allelopathic effects of Alliaria petiolata (garlic mustard), an aggressive invader of the understory of forests in North America, on the germination of two closely related species that co-occur with Alliaria, the American Geum laciniatum and the European Geum urbanum. Although no specific biochemical has been identified, they found that invasive North American populations of A petiolata greatly reduced the germination of naïve North American G laciniatum seeds, but had no effect on "experienced" European G urbanum seeds. Native European A petiolata, on the other hand, substantially reduced seed germination of North American $G$ laciniatum and European $G$ urbanum in similar proportions - a result that partially supports the novel weapons hypothesis.

The weak effects of root exudates of invasive species on their old neighbors and the strong effects of the same exudates on new and naïve neighbors suggest that plants can evolve tolerance to the unique rhizosphere biochemistry of co-occurring species. The scale at which evolved tolerance exists is unknown. It is unlikely that entire floras have evolved in response to particular root exudates, but it does seem that (-)-catechin and 8-hydroxyquinoline have influenced the evolution of at least some of the plant species living in the vicinity of $\mathrm{C}$ maculosa and $\mathrm{C}$ diffusa, perhaps in much the same way that herbicides exert strong selective pressures on plants. However, no coevolutionary relationships are possible with an herbicide.

Closely related species can differ in their sensitivity to the same allelochemical when they are from different continents, while distantly related plants can have similar sensitivities if they are from the same region. Thus, the historical coevolutionary trajectories discussed here are probably the result of relatively recent evolution and not from more ancient phylogenetic relationships. Such recent adaptation would suggest the possibility of future rapid evolution in plant populations that are experiencing invasion now. The evolution of exotics can be rapid (Müller-Schärer et al. 2004); perhaps natives can evolve tolerance to the competitive traits of invaders and ultimately coexist more evenly.

As mentioned above, there is no reason to think plants evolved to exude $(-)$-catechin and 8-hydroxyquinoline exclusively to gain a competitive advantage. Both chemicals are powerful chelators of nutrients such as phosphorus. Also, 8-hydroxyquinoline is an antimicrobial agent (Vivanco et al. 2004) and $(-)$-catechin is always exuded in a racemic form with an antimicrobial enantiomer (a molecule with a reversed, or mirror image), (+)-catechin (Bais et al. 2002). Other invasive species can have antimicrobial activity (Ehrenfeld 2003) and allelopathic chemicals released by some invasive species may alter nitrogen fixation (Wardle et al. 1994, 1998). Both (-)-catechin and 8-hydroxyquinoline could have evolved in response to selection pressure to improve nutrient acquisition and prevent microbial infection, and these chemicals are ineffective against native neighbors that have evolved tolerance. Perhaps it is only when these chemicals are introduced to naïve communities that their toxicity is manifest.

Many invasive species appear to have undergone a lag phase, during which they spread very slowly or not at all (Kowarik 1995). If the novel weapons hypothesis is a valid explanation for some invasions, then it would seem that species with these weapons would be highly successful from the beginning, and not undergo a lag phase. On the other hand, lag phases may occur for many other reasons, including the evolution of increased competitive ability and biological inertia in the resident community (von Holle et al. 2003). Lag phases might therefore occur even in exotic species that possess novel weapons.

\section{Antimicrobial novel weapons}

We have emphasized how novel biochemical interactions among plants may disrupt communities that are invaded by new species. However, plant-soil microbe interactions are also mediated by biochemical processes that are subject to the same kinds of selective forces. In other words, the effects of novel biochemical weapons on soil biota may also drive invasions. Combining plant and microbial species that have not shared evolutionary trajectories might also cause the striking changes in community composition and dominance that characterize many invasions.

Different microbial communities are associated with different plant species (Bever 1994; Grayston and Campbell 1996; Westover et al. 1997; Priha et al. 1999, 2001; Grayston et al. 2001; Klironomos 2002), probably due to 
species-specific rhizosphere biochemistry and the addition or removal of particular resources. It is reasonable to expect exotic species to also have species-specific effects on soil microbes, because they can have a strong influence on nutrient cycling (Vitousek 1990; Ehrenfeld et al. 2001). It is not known whether microbial changes caused by invaders are different enough from those that occur in native communities to allow invaders with little influence to transmogrify into dominant components of communities and exclude other species.

A great deal of evidence suggests that soil biota have important effects on the success of invasive plants (Klironomos 2002; Mitchell and Power 2003; Reinhart et al. 2003; Callaway 2004; Reinhart and Callaway in press; Wolfe and Klironomos unpublished) and that interactions between plants and their soil biota are based, in part, on biochemistry. However, despite the potential for biochemically based novel interactions between invasive plants and soil biota and our inclusion of such interactions in the novel weapons hypothesis, as yet there are no clear links between novel biochemistry, soil microbial communities, and invasive success. Invasive species such as Alliaria petiolata (garlic mustard) provide intriguing opportunities for such links. Like most members of its family, Alliaria is not mycorrhizal, and its root exudates are harmful to arbuscular mycorrhizae found in the soils where it invades in North America (Roberts and Anderson 2001). Comparative experiments on the effects of Alliaria on mycorrhizae in its native soils versus its effects on mycorrhizae in invaded soils could provide an empirical link between biochemical mechanisms, the importance of their novelty, and soil microbial communities.

\section{Novel weapons as a mechanism for EICA}

Despite the fact that the EICA hypothesis refers specifically to competitive ability, the underlying mechanism is explicitly rooted in the allocational trade-offs between investment in growth and investment in defense (Blossey and Nötzold 1995). However, there is no reason that selection for increased competitive ability should only arise from grow versus defend-type trade-offs. The mechanisms driving competitive ability, specifically the biochemical mechanisms described above, may also be the subject of selection.

Regardless of the factors that originally select for the novel chemical composition of the root exudates of invaders (eg need for nutrient chelation, defense, or antimicrobial action), possessing novel weapons is likely to have important evolutionary implications. If invaders possess traits, such as allelochemical weapons, that provide greater competitive advantages in their new habitats than in their original ranges, then selection pressure for the traits conferring competitive advantages may be much greater on the genotypes in the invaded regions than on the conspecific genotypes remaining at home. In other words, individuals that pump out a lot of effective poison might grow and reproduce more than individuals that do not. The rationale for exploring this alternative mechanism for the evolution of increased competitive ability, which we refer to as "allelopathic advantages against resident species" (AARS), is based on increasing evidence for the importance of rhizosphere biochemistry in invasions (Hierro and Callaway 2003). To be precise, we see AARS as a subset of the EICA hypothesis, but occurring as a consequence of an exotic species possessing a novel weapon. There are specific predictions of the "grow or defend" allocational trade-off hypothesis of EICA, and there are specific predictions of AARS. First, individuals from invasive populations should be better competitors where they have invaded than individuals from the source populations of the invader. However, this competitive superiority will not necessarily be related to the commonly measured greater size or fecundity because competitive superiority may not be directly related to resource uptake. The fundamental prediction of AARS is that invasive populations will be more allelopathic than source populations. Presumably this could occur as a result of selection for more toxic compounds, or selection for the production of greater amounts of an existing toxin. To our knowledge, there is no unambiguous evidence for such a biogeographical difference. For $\mathrm{C}$ diffusa and $\mathrm{C}$ maculosa, the concentrations of their allelochemicals (8-hydroxyquinoline and $( \pm)$-catechin) are about twice as high in the rhizospheres of invasive populations than in rhizospheres of native populations (Bais et al. 2003; Vivanco et al. 2004), but the effects of different microbial consumption rates or population densities have not been separated from individual exudation rates. It should be mentioned that there is no $a$ priori reason to assume that directional selection will increase allelopathic output. If a very small amount of chemical is very effective at first, but not as effective later (a rapidly saturating benefit curve), and if the cost of production increases at least linearly, it is feasible that allelochemical production could decrease in the new range. Only empirical studies will tell.

\section{Conclusions}

Investigation of the role of species-specific rhizosphere biochemistry in plant ecology and evolution may provide insight into remarkable phenomena involving successful plant invasions. Recent research suggests conceptual parallels between the success of exotic human invasions and the success of exotic plant invasions - the possession of novel weapons.

\section{Acknowledgements}

We gratefully acknowledge support provided to Ragan Callaway from the National Science Foundation, the USDA, The Aldo Leopold Wilderness Institute, and the Civilian Research and Development Foundation. 


\section{References}

Agrawal AA and Kotanen PM. 2003. Herbivores and the success of exotic plants: a phylogenetically controlled experiment. Ecol Lett 6: 712-15.

Bais HP, Walker TS, Stermitz FR, et al. 2002. Enantiomeric-dependent phytotoxic and antimicrobial activity of $( \pm)$-catechin. A rhizosecreted racemic mixture from spotted knapweed. Plant Physiol 128: 1173-79.

Bais HP, Vepachedu R, Gilroy S, et al. 2003. Allelopathy and exotic plants: from genes to invasion. Science 301: 1377-80.

Baldwin IT. 2003. At last, evidence of weapons of mass destruction. Science STKE pe42.

Beckstead J and Parker IM. 2003. Invasiveness of Ammophila arenaria: release from soil-borne pathogens? Ecology 84: 2824-31.

Bever JD. 1994. Feedback between plants and their soil communities in an old field community. Ecology 75: 1965-77.

Blossey B and Nötzold R. 1995. Evolution of increased competitive ability in invasive nonindigenous plants: a hypothesis. J Ecology 83: 887-89.

Bossdorf O, Prati D, Auge H, and Schmid B. 2004. Reduced competitive ability in an invasive plant. Ecol Lett 7: 346-53.

Callaway RM. 2002. The detection of neighbors by plants. Trends Ecol Evol 17: 104-05.

Callaway RM and Aschehoug ET. 2000. Invasive plants versus their new and old neighbors: a mechanism for exotic invasion. Science 290: 521-23.

Callaway RM, DeLuca T, and Ridenour WM. 1999. Herbivores used for biological control may increase the competitive ability of the noxious weed Centaurea maculosa. Ecology 80: 1196-201.

Callaway RM and Hierro JL. Resistance and susceptibility of plant communities to invasion: revisiting Rabotnov's ideas about community homeostasis. In: Reigosa, MJ, N Pedrol and L González (Eds.) Allelopathy: a physiological process with ecological implications. Boston, MA: Kluwer Academic Press. In press.

Callaway RM, Hierro JL, and Thorpe AS. Evolutionary trajectories in plant and soil microbial communities: plant invasions and the geographic mosaic of coevolution. In: Sax DF, Gaines SD, and Stachowicz JJ (Eds). Exotic species bane to conservation and boon to understanding: ecology, evolution and biogeography. Sunderland, MA: Sinauer. In press.

Callaway RM, Thelen GG, Rodriguez A, and Holben WE. 2004. Release from inhibitory soil biota in Europe may promote exotic plant invasion in North America. Nature 427: 731-33.

Crawley MJ. 1987. What makes a community invasible? In: Gray AJ, Crawley MJ, and Edwards PJ (Eds). Colonization, succession and stability. London, UK: Blackwell Scientific.

Crawley MJ. 1989. Insect herbivores and plant population dynamics. Annu Rev Entomol 34: 531-64.

Crawley MJ. 1997. Plant ecology. London, UK: Blackwell Science.

Daehler CC and Strong DR. 1997. Reduced herbivory resistance in introduced smooth cordgrass (Spartina alterniflora) after a century of herbivore-free growth. Oecologia 110: 99-108.

DeWalt SJ, Denslow JS, and Ickes K. 2004. Natural-enemy release facilitates habitat expansion of the invasive tropical shrub Clidemia hirta. Ecology 85: 471-83.

Diamond J. 1997. Guns, germs, and steel: the fates of human societies. New York, NY: Random House.

Elton CS. 1958. The ecology of invasions. London, UK: Methuen.

Ehrenfeld JG. 2003. Effects of exotic plant invasions on soil nutrient cycling processes. Ecosystems 6: 503-23.

Ehrenfeld JG, Kourtev P, and Huang W. 2001. Changes in soil functions following invasions of exotic understory plants in deciduous forests. Ecol Appl 11: 1287-300.

Fitter A. 2003. Making allelopathy respectable. Science 301: 1337-38.

Flores HE. 1999. "Radical" biochemistry: the biology of root-specific metabolism. Trends Plant Sci 4: 220-26
Grayston SJ and Campbell CD. 1996. Functional biodiversity of microbial communities in the rhizosphere of hybrid larch (Larix eurolepis) and Sitka spruce (Picea sitchensis). Tree Physiol 16: $1031-38$

Grayston SJ, Griffith GS, Mawdsley JL, Campbell CD, and Bardgett RD. 2001. Accounting for variability in soil microbial communities of temperate upland grassland ecosystems. Soil Biol Biochem 33: 533-51.

Herms DA and Mattson WJ. 1992. The dilemma of plants: to grow or defend. Q Rev Biol 67: 283-335.

Hierro JL and Callaway RM. 2003. Allelopathy and exotic plant invasion. Plant Soil 256: 25-39.

Jakobs G, Weber E, and Edwards PJ. 2004. Introduced plants of the invasive Solidago gigantea (Asteraceae) are larger and grow denser than conspecifics in the native range. Divers Distrib 10: $11-19$.

Klironomos J. 2002. Feedback with soil biota contributes to plant rarity and invasiveness in communities. Nature 417: 67-70.

Kowarik I. 1995. Time lags in biological invasions with regard to the success and failure of alien species. In: Py ek P, Prach K, Rejmánek M, and Wade M (Eds). Plant invasions - general aspects and special problems. Amsterdam, Netherlands: SPB Academic Publishing.

Leger EA and Rice KJ. 2003. Invasive California poppies (Eschscholzia californica Cham.) grow larger than native individuals under reduced competition. Ecol Lett 6: 257-64.

Lesica P and Hanna D. 2004. Indirect effects of biological control on plant diversity vary across sites in Montana grasslands. Conserv Biol 18: 444-54.

Levine JM, Vilá M, D'Antonio CM, et al. 2002. Mechanisms underlying the impacts of exotic plant invasions. P Roy Soc Lond B Bio 270: 775-81.

Mack RN, Simberloff D, Lonsdale WM, et al. 2000. Biotic invasions: causes, epidemiology, global consequences and control. Ecol Appl 10: 689-710.

Mahall BE and Callaway RM. 1992. Root communication mechanisms and intracommunity distributions of two Mojave Desert shrubs. Ecology 73: 2145-51.

Mallik AU and Pellissier F. 2000. Effects of Vaccinium myrtillus on spruce regeneration: testing the notion of coevolutionary significance of allelopathy. J Chem Ecol 26: 2197-209.

Maron JL and Vilà M. 2001. Do herbivores affect plant invasion? Evidence for the natural enemies and biotic resistance hypotheses. Oikos 95: 363-73.

Maron JL, Vilá M, Bommarco R, et al. 2004. Rapid evolution of an invasive plant. Ecol Mono 74: 261-80.

Mitchell CG and Power AG. 2003. Release of invasive plants from fungal and viral pathogens. Nature 421: 625-27.

Muir AD and Majak W. 1983. Allelopathic potential of diffuse knapweed (Centaurea diffusa) extracts. Can J Plant Sci 63: 989-96.

Müller-Schärer H and Schroeder D. 1993. The biological control of Centaurea spp. in North America: do insects solve the problem? Pestic Sci 37: 343-53.

Müller-Schärer H, Schaffner U, and Steinger T. 2004. Evolution in invasive plants: implications for biological control. Trends Ecol Evol 19: 417-22.

Pearson DE and Callaway RM. 2003. Indirect effects of host-specific biocontrol agents. Trends Ecol Evol 18: 456-61.

Prati D and Bossdorf O. 2004. Allelopathic inhibition of germination by Alliaria petiolata (Brassicaceae). Am J Bot 91: 285-88.

Priha O, Grayston SJ, Pennanen T, and Smolander A. 1999. Microbial activities related to $\mathrm{C}$ and $\mathrm{N}$ cycling, and microbial community structure in the rhizospheres of Pinus sylvestris, Picea abies and Betula pendula seedlings in an organic and mineral soil. FEMS Microbiol Ecol 30: 187-99.

Priha O, Grayston SJ, Hiukka R, et al. 2001. Microbial community structure in soils under Pinus sylvestris, Picea abies and Betula pendula. Biol Fert Soils 33: 17-24. 
Rabotnov TA. 1982. Importance of the evolutionary approach to the study of allelopathy. Ekologia No 3: May-June: 5-8.

Ridenour WL and Callaway RM. 2001. The relative importance of allelopathy in interference: the effects of an invasive weed on a native bunchgrass. Oecologia 126: 444-50.

Ridenour WL and Callaway RM. 2003. Root herbivores, pathogenic fungi, and competition between Centaurea maculosa and Festuca idahoensis. Plant Ecol 169: 161-70.

Reinhart KO and Callaway RM. Soil biota facilitate exotic Acer invasions in Europe and North America. Ecol Appl. In press.

Reinhart KO, Packer A, Van der Putten WH, and Clay K. 2003. Plant-soil biota interactions and spatial distribution of black cherry in its native and invasive ranges. Ecol Lett 6: 1046-50

Roberts KJ and Anderson RC. 2001. Effect of garlic mustard [Alliaria petiolata (Beib. Cavara and Grande)] extracts on plants and arbuscular mycorrhizal (AM) fungi. Am Midl Nat 146: $146-52$.

Siemann E and Rogers WE. 2001. Genetic differences in growth of an invasive tree species. Ecol Lett 4: 514-18.

Siemann E and Rogers WE. 2003. Increased competitive ability of an invasive tree limited by an invasive beetle. Ecol Appl 13: 1503-07.

Thompson JN. 1999. Specific hypotheses on the geographic mosaic of coevolution. Am Nat 153: 1-14.

Van Kleunen M and Schmid B. 2003. No evidence for evolutionary increased competitive ability (EICA) in the invasive plant Solidago canadensis. Ecology 84: 2824-31.

Vilà M, Gomez A, and Maron JL. 2003. Are alien plants more competitive than their native conspecifics? A test using Hypericum perforatum. Oecologia 137: 211-15.

Vitousek PM. 1990. Biological invasions and ecosystem processes: towards an integration of population biology and ecosystem studies. Oikos 57: 7-13.

Vivanco JM, Bais HP, Stermitz FR, et al. 2004. Biogeographical variation in community response to root allelochemistry: novel weapons and exotic invasion. Ecol Lett 7: 285-92.

Von Holle D, Delacourt HR, and Simberloff D. 2003. The importance of biological inertia in plant community resistance to invasion. J Veg Sci 14: 425-32.

Wardle DA, Nicholson KS, Ahmed M, and Rahman A. 1994.
Interference effects of the invasive plant Carduus nutans L against the nitrogen fixation ability of Trifolium repens L Plant Soil 163: 287-97.

Wardle DA, Nilsson M-C, Gallet C, and Zackrisson O. 1998. An ecosystem-level perspective of allelopathy. Biol Rev 73: 301-19.

Westover KM, Kennedy AC, and Kelley SE. 1997. Patterns of rhizosphere microbial community structure associated with cooccurring plant species. J Ecol 85: 863-73.

Whittaker RH. 1951. A criticism of the plant association and climatic climax concepts. Northwest Sci 25: 17-31.

Williams JR. 1954. The biological control of weeds. In: Report of the Sixth Commonwealth Entomological Congress. London, UK.

Willis AJ and Blossey B. 1999. Benign climates don't explain the increased plant size of non-indigenous plants: a cross-continental transplant experiment. Biocontrol Sci Techn 9: 567-77.

Willis AJ, Memmott J, and Forrester RI. 2000. Is there evidence for the post-invasion evolution of increased size among invasive plant species? Ecol Lett 3: 275-83.

Wolfe LM. 2002. Why alien invaders succeed: support for the escape-from-enemy hypothesis. Am Nat 160: 705-11.

\section{New series: invitation to authors}

This paper is the first in a new occasional series under the heading "Concepts and Questions". These essay-style articles will provide authors with the opportunity to outline innovative theories not yet accepted by the scientific community, to discuss old ideas that deserve to be revisited in the light of new information, or to provide interesting commentaries on a hot topic in ecology, environmental science, or a related specialty.

Criteria: The topic and level of writing must be accessible and interesting, even to those unfamiliar with the subject. Length: about 2500-3000 words; abstract: up to 150 words; references: 25-30. All essays will be subject to peer review before they are accepted for publication, with emphasis placed on the clarity and logic of the arguments.

Please contact the Editor-in-Chief, Dr Sue Silver (suesilver@esa.org) for further information. 